Susanne Ørnager, lektor emerita, Institut for Kommunikation, Københavns Universitet, fpm434@hum.ku.dk

Haakon Lund, lektor, Institut for Kommunikation, Københavns Universitet, hl@hum.ku.dk

\title{
Billedindeksering og sociale medier
}

\begin{abstract}
This article focuses on the methodologies, organization, and communication of digital image collection research that utilizes social media content. "Image" is here understood as a cultural, conventional, and commercial-stock photo-representation. Two methodologies i.e. PRISMA and Grounded Theory are employed to examine, categorize and analyze images and comprehend how humans consider them. The literature review covers research since 2005, when major social media platforms emerged. It demonstrates that the images on social media have not changed the overall direction of research into image indexing and retrieval, though new topics on crowdsourcing and tagging have emerged in it. A citation analysis includes an overview of co-citation maps that demonstrate the nexus of image research literature and the journals in which they appear. The results point to new possibilities influencing the research by providing large image collections as new testbeds for improving or testing research hypothesis on a new scale.
\end{abstract}

Keywords: Billedindeksering, billedgenfinding, fotografier, sociale medier, billedfacetter, litteraturanalyse af billeder, PRISMA, Grounded Theory, citationsanalyse af billeder, billedbehandling, tekstgenkendelse, billedalgoritmer.

\section{Introduktion}

Siden 2005 er der sket en voldsom stigning i antallet af billeder, der gøres tilgængelige på sociale medier, og dermed giver nye udfordringer for hvorledes billeder kan genfindes. Billede defineres i Informationsordbogen (2018) som "Todimensional eller overvejende todimensional repræsentation af genstande eller former". Fotografi defineres som "Originalt billede, der enten er permanent fikseret i et lysfølsomt materiale som en unik optagelse med et analogt fotografiapparat, eller som foreligger i digital form (jf. digitalt fotografi) med henblik på skærmvisning og evt. udprintning i permanent fikseret form. Et fotografi er kun et originalfotografi hvis det ikke har eksisteret $f \varnothing r$ ". Billedindeksering defineres samme sted som "Beskrivelse eller automatisk analyse af billeder med henblik på genfinding", man skelner her mellem "begrebsbaseret og indholdsorienteret indeksering" af billeder. Både billeder og fotografier hører ifl. Informationsordbogen til de to samme klynger: "Billeder" og "Informationsbærende materialer". I denne artikel benyttes Informationsordbogens definitioner og termerne billede og fotografi behandles som synonymer. 
De sociale platforme stiller en infrastruktur til rådighed, som har betydet, at der er skabt store billedsamlinger faciliteter som gør det nemmere og hurtigere at forske i forskellige måder at indeksere, lagre og genfinde fotos på.

Sociale medier bliver ofte brugt til at beskrive tjenester som Twitter, Facebook, Instagram, Snapchat, etc. Obar and Wildman (2015) samler flere definitioner:

1. Social media services are (currently) Web 2.0 Internet-based applications.

2. User-generated content is the lifeblood of social media.

3. Individuals and groups create user-specific profiles for a site or app designed and maintained by a social media service.

4. Social media services facilitate the development of social networks online by connecting a profile with those of other individuals and/or groups.

Selvom listen ovenfor kun kan kaldes "a statement of intent", er det blevet foreslået af Nations (2017) at operere med de 4 punkter som en arbejdsdefinition "web-based communication tools that enable people to interact with each other by both sharing and consuming information" (Nations, 2017).

Forskellen mellem sociale og professionelle medier er, at de første bliver beskrevet som et kommunikationsværktøj, og de sidste mest bruges om forskning og kommercielle interesser. Fotografier håndteres af forskere $\mathrm{i}$ institutioner som biblioteker, arkiver og museer $\mathrm{i}$ forskellige organisationer og kommercielle bureauer. Fotos bliver lagret og genfundet, hvilket kræver indekseringspolitikker i.e. fælles regler til lagring og genfinding. Fotografier er en del af vores historie og verdenshukommelse altså "Memory of the World".

Analysen af et foto kan ifølge flere forskere (Barthes, 1964; Ornager, 1997; Panofsky, 1962; Shatford, 1986) inkludere flere niveauer i.e. et $O f$ eller faktuelt niveau og et About eller expressionelt niveau, hvor det sidste er baseret på den kulturelle gruppe, som anvender fotografiet. De forskellige aspekter skal vises i indekseringen, da det er vigtigt for de spørgsmål, som stilles til et system, som indeholder fotos. Shatfords (Layne, 1994) niveauer viser fire facetter (who, what, where, and when), og det er foreslået, at hvert niveau indeholder tre aspekter udviklet af Panofsky (1962): det specifikke Of (Iconography), det generiske Of (Pre-iconography), og det abstrakte About (Iconology). Matrixen vist (Stewart, 2010) i tabel 1 refereres til som Panofsky/Shatford matrixen. 


\begin{tabular}{|l|l|l|l|}
\hline Shatford/Panofsky & $\begin{array}{l}\text { Iconography } \\
\text { Specifics }=\mathbf{S}\end{array}$ & $\begin{array}{l}\text { Pre-iconography } \\
\text { Generics }=\mathbf{G}\end{array}$ & $\begin{array}{l}\text { Iconology } \\
\text { Abstracts }=\mathbf{A}\end{array}$ \\
\hline Who & $\begin{array}{l}\text { Individually named person, } \\
\text { group, thing S1 } \\
\text { Example: Obama, Eiffel } \\
\text { tower, Sherlock Holmes, } \\
\text { Jesus }\end{array}$ & $\begin{array}{l}\text { Kind of person or thing G1 } \\
\text { Example: woman, knight, } \\
\text { tree, lion }\end{array}$ & $\begin{array}{l}\text { Mythical or fictitious being } \\
\text { A1 } \\
\text { Example: Mother earth, } \\
\text { strength, hope, fear, Jesus } \\
\text { (represented as a lam) }\end{array}$ \\
\hline What & $\begin{array}{l}\text { Individually named event, } \\
\text { action S2 } \\
\text { Example: Olympic Games } \\
\text { in London 2012 }\end{array}$ & $\begin{array}{l}\text { Kind of event, action, } \\
\text { condition G2 } \\
\text { Example: party, teach, } \\
\text { dance, sleep, smile }\end{array}$ & $\begin{array}{l}\text { Emotion or abstraction A2 } \\
\text { Example: hopeful, creative }\end{array}$ \\
\hline Where & $\begin{array}{l}\text { Individually named } \\
\text { geographical location S3 } \\
\text { Example: Japan, } \\
\text { Smithsonian National Zoo }\end{array}$ & $\begin{array}{l}\text { Kind of place: } \\
\text { geographical, architectural } \\
\text { G3 } \\
\text { Example: outdoors, } \\
\text { botanical garden, road, } \\
\text { kitchen }\end{array}$ & $\begin{array}{l}\text { Place symbolized A3 } \\
\text { Example: Hell, Heaven }\end{array}$ \\
\hline When & $\begin{array}{l}\text { Cyclical time: season, time } \\
\text { of day G4 } \\
\text { Example: evening, spring, } \\
\text { sunrise, Easter }\end{array}$ & $\begin{array}{l}\text { Emotion, abstraction } \\
\text { Symbolized by time A4 } \\
\text { Example: June 2015 } \\
\text { Example: post-apocalypse, } \\
\text { past, future }\end{array}$ \\
\hline
\end{tabular}

Tabel 1. Panofsky/Shatford klassifikationsmatrixen (Stewart, 2010)

Vores mål er ikke at anbefale matrixen kun at påpege, at der er forskellige forståelser af niveauerne i et billede (Christensen, 2017).

Målet med artiklen er, på baggrund af en litteraturanalyse, at afdække hvorledes fremkomsten af sociale (billed)medier har påvirket den forskning, der siden 2005 er publiceret i forskningslitteraturen indenfor det informationsvidenskabelige fagfelt specielt i forhold til billedindeksering og genfinding. Metaforskning på billedområdet er uprøvet, og resultatet kan påvise andre og nye tiltag i forhold til billedbehandling. Vi opstiller derfor følgende overordnede forskningsspørgsmål:

1. Ændres billedforskning efter den eksplosive fremvækst af fotografier og den forandrede infrastruktur på de sociale medier?

Tre undersøgelser knytter sig til forskningsspørgsmålet:
a. Valg af metoder til afgrænsning og kodificering af billedforskningsartikler.
b. Litteraturanalyse af billedforskningen efter fremkomsten af sociale medier fra 2005-2017.
c. Bibliometrisk analyse af billedforskningsdomænet.

Endelig:

2. Hvilke nye muligheder findes indenfor indeksering og genfinding af billeder.

For at besvare forskningsspørgsmålet præsenteres metoder til udvælgelse og kategorisering af artikler om billedforskning. Systematiseringen af litteraturoversigten giver et detaljeret billede af forskningen, der er foretaget fra 2005-2017. En bibliometrisk analyse er benyttet for at afdække videnstrukturen indenfor feltet. Til slut bliver nye udviklinger indenfor manuel og automatisk indeksering og genfinding af billeder beskrevet. 


\section{Metoder og analyse}

Den præsenterede litteraturoversigt er en analyse af akademisk billedforskning fra de sociale mediers opståen i 2005 til året 2017. Først beskrives metodologien PRISMA (Preferred Reporting Items for Systematic Reviews and Meta-Analyses guidelines), som anvendes til at finde den relevante billedlitteratur, og derefter Grounded Theory som bruges til at analysere de fremfundne dokumenter.

PRISMA (Moher et al., 2009) metoden er et evidensbaseret minimumssæt af elementer, som specielt benyttes indenfor sundhedssystemet. Det kan dog også anvendes som basis for at studere andre forskningsområder. PRISMA fokuserer på måder, hvorved forfattere kan sikre transparens og fuldstændig rapportering af forskning og dets brug ved at bruge kritisk evaluering.

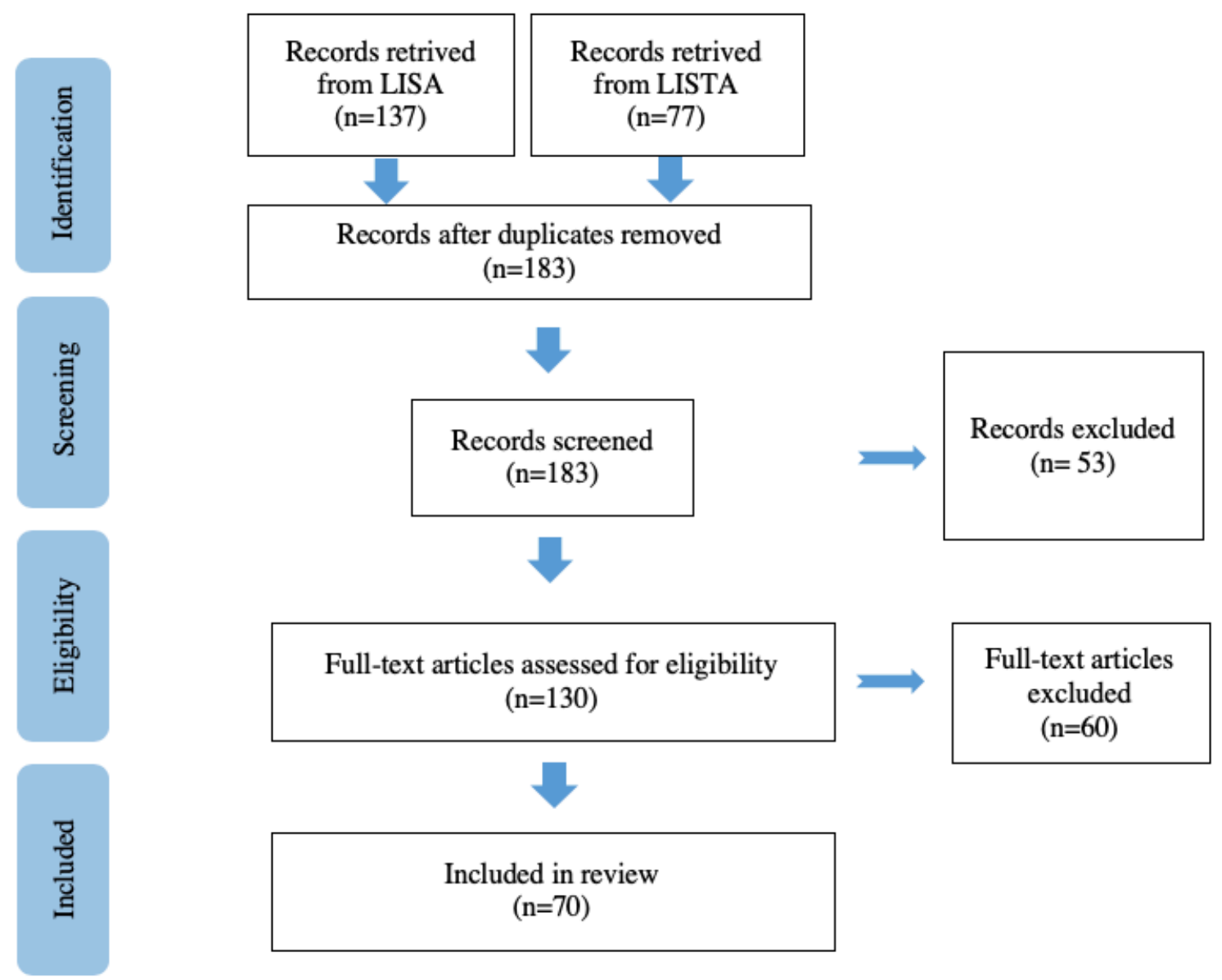

Figur 1. PRISMA oversigt over søgestrategi

To centrale databaser indenfor det informationsvidenskabelige fagfelt, LISA (Library and Information Science Abstracts) og LISTA (Library, Information Science, and Technology Abstracts), blev afsøgt for litteratur til oversigten. De følgende engelske termer blev benyttet: controlled vocabulary, crowdsourcing, image indexing, image retrieval, images, photo, photographic indexing, photographic retrieval, tags, subject access, subject headings, og visual information. Ifølge PRISMA skal posterne screenes for relevans, og følgende kriterier blev anvendt til inklusion: (1) artikler udgivet mellem 2005 og 2017 begge år blev inkluderet, (2) artikler på engelsk, (3) peer-reviewed konference- og tidsskriftartikler. Udeladt blev: (1) artikler baseret på overvejende tekniske beskrivelser, og (2) artikler som primært fokuserede på malerier. Den fulde tekst af de resterende 130 dokumenter blev derefter gennemset for yderligere evaluering i forhold til udvælgelseskriterierne. Vurderingen resulterede $\mathrm{i}$, at der blev inkluderet 70 artikler i oversigten (figur 1). Grounded Theory er valgt til den endelige 
analyse af litteraturen. Grounded Theory er en kvalitativ metode udviklet af Glaser and Strauss (1967) og virkeliggjort af Strauss og Corbin (1990; 1998) og Glaser (1992).

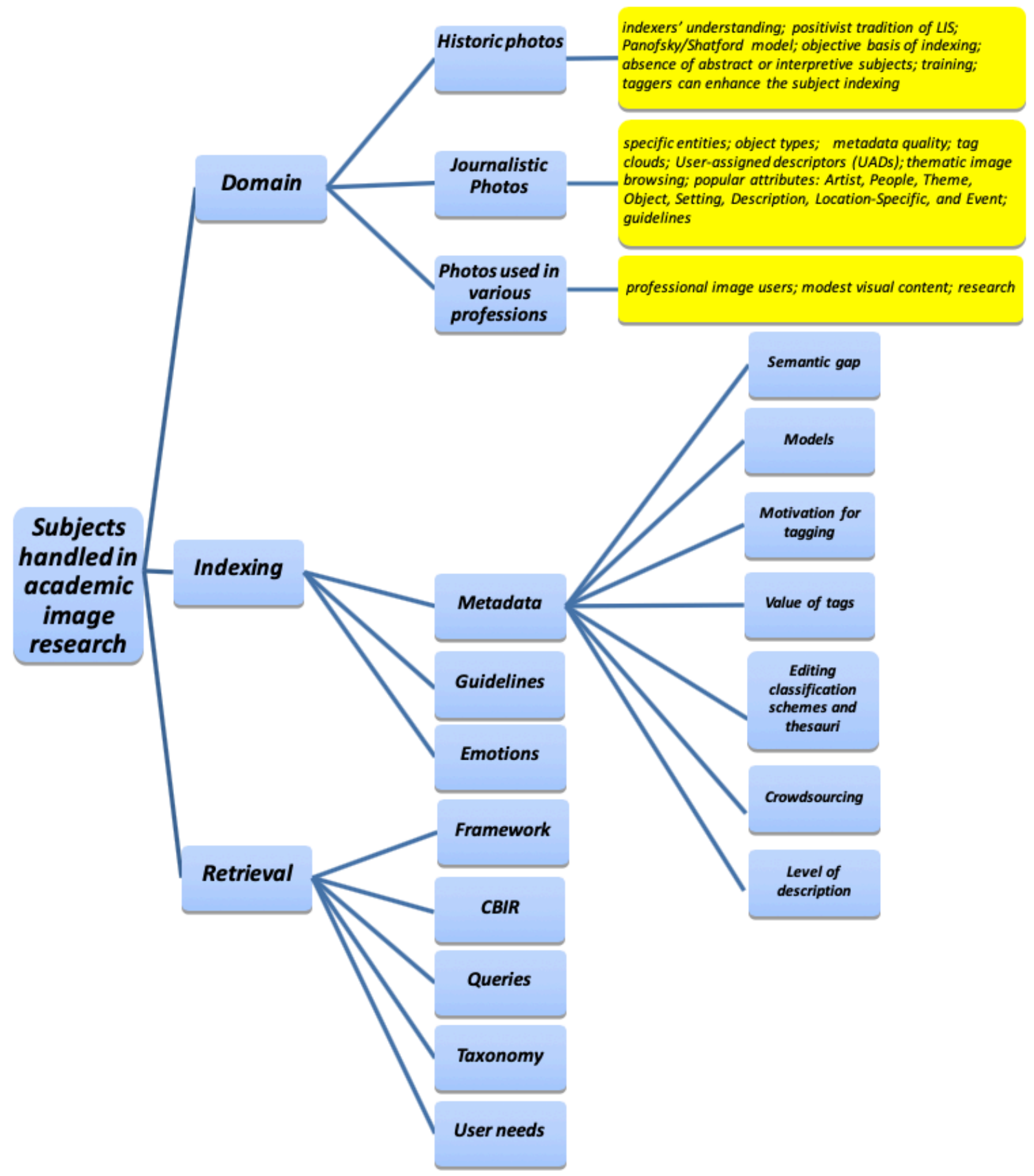

Figur 2. Code, Categories og Sub-categories udledt v.h.a. Grounded Theory hvor Domains har sub-categorier og properties, og sub-categorien Metadata har sub-sub-categorier. 
Teknikken til dataindsamling og -analyse kan beskrives, som at den tillader koncepter og kategorier at opstå fra data. I Grounded Theory arbejdes med koder (codes/core categories), kategorier (categories), og egenskaber (properties). Udviklingen af kategorier er baseret på observationer, interviews og spørgeskemaer såvel som på eksisterende litteratur. Grounded Theory er opdagelsen af nye mønstre i data (Walsh et al., 2015). Definitionerne blev etableret af Strauss og Corbin (1990, p. 61). De definerede Code som "Conceptual labels placed on discrete happenings, events, and other instances of phenomena"; Category som "A classification of concepts" og Property som "Attributes or characteristics pertained to a category". Strauss og Corbins definitioner, som bruges på vores "data" om billeder, kaldes klasser, kategorier og egenskaber. Vores data bliver først analyseret via "open coding". Baseret på induktion anskueligg $ø r$ vi individuelle tilstedeværelser, og når vi har tilstrækkeligt med forekomster/begivenheder til at observere et mønster, giver vi et navn til gruppen, d.v.s. et kategorinavn. Flere kategorier kan danne en klasse eller code. Hovedkategorien giver en slags empirisk "road map", som kan benyttes ved yderligere dataindsamling og sortering og til at foreslå sub-kategorier. Forekomster kan også repræsentere egenskaber ved sub-kategorier. I litteraturoversigten identificerede vi hovedkategorien the code som "Subjects handled in academic image research" og underdelte den i tre kategorier kaldet Domains, Indexing og Retrieval. Sub-kategorier og egenskaber blev deduceret fra hovedkategorierne (se figur 2). Resultatet af processen blev sammenholdt med spørgsmålet om "Subjects handled in academic image research undertaken in the period 2005-2017."

\section{Litteraturanalyse 2005-2017}

Med reference til figur 2 ses det, at de 70 peer-reviewed konferenceindlæg og tidsskriftartikler kan deles i de tre kategorier Domains, Indexing, og Retrieval. Generelt kan det bemærkes, at den sociale fotoside Flickr er anvendt til mange af de refererede tests indenfor de tre kategorier. Den formodede grund er, at fotos fra Flickr har få copyright restriktioner. Testpersonerne er primært studerende fra Informationsvidenskab.

I kategorien Domains er der tre sub-kategorier, som tilkendegiver, at der ikke er store forandringer i resultaterne fra artiklerne efter opkomsten af de sociale medier. Historic photos er navnet på den første sub-kategori, og det er tydeligt, som Spinger et al's. (2008) rapport om "Library of Congress (LC) Flickr Pilot Project" indikerer, at der er stor interesse fra brugerne for at give supplerende tags til allerede indekserede fotos i professionelle historiske billedbaser. Analyserne i Litteraturgennemgangen viser derimod også, at professionel indeksering sjældent er gearet til brugernes behov, og at forskellige professioners forn $\varnothing$ denheder bør overvejes i indekseringen. Andre resultater tilkendegiver i øvrigt, at indeksører fokuserer på Panofsky/Shatford modellens præ-ikonografiske beskrivelser, medens brugerne også er interesserede i andet end det generiske niveau (Stewart, 2010).

Artiklerne i den anden sub-kategori Journalistic photos beskriver, hvordan organisationer og medier (aviser, TV, fotoarkiver etc.) kategoriserer deres fotografier. Den generelle indeksering demonstrerer en deling mellem specifikke enheder og typer af genstande, hvor den første kategori repræsenterer personer i fotografiet, medens den sidste peger på forskellige motiver, hvor personerne ikke er det vigtigste. De forskellige journalistiske medier har forskellige klassifikationer baseret på egenskaberne/attributterne i fotoet, og når det kommer til genfinding, er der forslag fra forskerne om at "græsse" v.h.a. specifikke attributter. (Westman and Oittinen, 2006; Neal, 2008; Chen et al., 2010).

Artiklen i den tredje sub-kategori Photos used in various professions beskriver nye tiltag i akademisk billedforskning, som fokuserer på brugen i forskellige domæner. Resultaterne peger på, at visuelt indhold er forbavsende ulige benyttet indenfor forskellige discipliner. Der er ingen indikationer, der peger på, at der er sket en betydelig forandring $\mathrm{i}$ indekseringen efter introduktionen af de sociale medier. (Beaudoin, 2014).

Indeksering og søgning komplimenterer hinanden, og adskillelsen i denne artikel er helt baseret på forfatternes skøn. I kategorien Indexing er der tre sub-kategorier.

Metadata er den første sub-kategori, og inkluderer artikler, som inddeles i syv sub-sub-kategorier. Semantic Gap (1) er en beskrivelse af forskellen mellem et menneskes beskrivelse af et visuelt medie og en maskines beskrivelse 
af samme. I 2005 var der meget debat om behovet for at forbedre funktionaliteten af den daværende automatiske teknik. Nye paradigmer blev diskuteret, men der ses ingen forandringer efter introduktionen af sociale medier. Models (2) beskriver forskellige undersøgelser, hvor modeller fokuserer på en blandet indekseringstilgang af fotografier, specielt på Flickr. Forskerne overvejer forskellige nye kategorier, som brugere af Flickr kunne anvende til udvikling af digitale fotosamlinger. Flickrfotografier bliver studeret for deres eventuelle anvendelse som ressourcer i forskellige domæner. Her er sociale netværk forskningsfokus, og forskerne koncentrerer sig udelukkende om dem. Motivation for Tagging (3) bliver behandlet i flere forskningsartikler, hvor domænet bliver delt i private og professionelle områder. På det private område er der spørgsmålet om "dovenskab" i forhold til at tilføje tags. Det ser ud til, at mulighederne for automatisk tildeling af metadata på mobile enheder i.e. point-of-capture stimulere brugerne til at tilføje yderlige metadata. Personlig/privat motivation er kommunikation med venner og familie, medens tagging bliver set som et organiseringstiltag for offentligheden. Generelt kan man sige, at både social tilstedeværelse og individuel motivation påvirker brugernes taggingniveau. Det professionelle område berører editering af klassifikationsskemaer og tesaurusser, og det tester forholdet mellem brugertags og de tags, der fagmæssigt bliver tildelt tesaurusser. Artiklerne fokuserer også på "basic-level theory" (Rosch et al., 1976). Teorien arbejder med tre niveauer baseret på en antagelse om, at mennesket kategoriserer simpelt. Niveauerne er "basic; subordinate; og superordinate" altså Stol; Gyngestol; og Møbler. Artiklerne behandler spørgsmålet om, hvor ofte anvendte superordinate- og subordinate-level termer skal inkluderes. Artikler under Motivation for Tagging sætter ikke spørgsmål ved tidligere forslag til billedindeksering, men overvejer nye forskningsspørgsmål, og her er sociale netværker et kernepunkt $i$ undersøgelserne. Value of Tags (4) demonstrerer, at metadata, der udtrykker generiske termer, er mere almindelige i billedbeskrivelse end specifikke termer, og at abstrakte begreber sjældent anvendes. Populære tags på Flickr følger denne tendens. Resultaterne af andre tests viser, at et mix af tags er bedre til billedsøgning end optimering af enten generiske eller specifikke termer. Nogle test viser også, at kvalitetskriterierne til billedindeksering er forskellige fra dem til dokumentindeksering - det drejer sig især om kontekst, stemninger, betydning og detaljeringsniveau. Der er i øvrigt en stigende interesse for igen at vurdere fotografierne i kulturarvsmaterialet. Artikler under Editing Classification Schemes and Thesauri (5) studerer brugernes tags, og om de kan anvendes til tesaurusdesign, som kan reflektere de unikke funktioner $\mathrm{i}$ billeddokumenter. Shatfords facetkategorier (1986; Layne, 1994) og Rosch et al.s (1976) basic-level theory evalueres for at foreslå nye begreber til en tesaurus. Resultatet viser, at den bedste tilgang især for color og generiske kategorier er at fokusere på basic-level termer og kun sporadisk at inkludere over- eller underordnede termer. Testen viste også, at inklusion af brugernes tags resulterer i, at man når et meget stort publikum (Springer et al., 2008). Artikler under Crowdsourcing (6) behandler denne nye metode til indeksering. Der findes flere forskningsartikler, der definer crowdsourcing og tilgange til udvikling af en taxonomi om crowdsourcing, som baseres på jobkompleksitet og studiet af virtuelle grupper. Nogle studier hævder, at tekstbaseret søgeteknik (og dermed indeksering) stadig er den mest effektive og nøjagtige metode til billedindeksering/søgning. Der er behov for at udvikle visuelle læsefærdigheder (visual literacy). Artikler under Level of Description (7) studerer, hvilket niveau der er nødvendigt for billedbeskrivelse, og hvilke indekseringsværktøjer, der er mest succesrige. Egenskaber på et såkaldt lavt niveau i billedbeskrivelse såsom form, tekstur og farve er nødvendige for forståelsen af et foto, men definerer ikke fotografiet. Tekstbaseret indeksering/søgning er ifølge forskningsresultater stadig den mest akkurate metode. Som også bemærket i tidligere studier ser man også her, at taggene er koncentreret på det generiske niveau, og fokus er på at forbedre dette niveau. Det konnotative niveau er meget subjektivt, og brugerne anvender fortællinger til at forbedre dette trin. (Enser, Sandom and Lewis, 2005; Ames and Naaman, 2007; Jörgensen, 2007; Rafferty and Hidderley, 2007; Stvilia and Jörgensen, 2009; Yoon, 2009; Angus, Stuart and Thelwall, 2010; Nov and Ye, 2010; Stvilia and Jörgensen, 2010; Ransom and Raferty, 2011; Terras, 2011; Beaudoin, 2012; Estellés-Arolas and González-Ladrón-de-Guevara, 2012; Petek, 2012; Stvilia, Jörgensen, and Wu, 2012; Fauzi and Belkhatir, 2013; Huang and Jörgensen, 2013; Jörgensen, Stvilia and Wu, 2013; Drew and Guillemin, 2014; Fauzi and Belkhatir, 2014; Klenczon and Rygiel, 2014; Kovács and Takács, 2014; Nakatsu, Grossman and Lacovou, 2014; Rafferty and Albinfalah, 2014; Zeng, Graces and Žumer, 2014; Benson, 2015; Lin et al., 2015; Beaudoin, 2016).

Artiklerne i den anden sub-kategori, Guidelines, beskriver ideer til udvikling af vejledende principper - regler for billedindekseringsskabeloner bliver også foreslået. Der er fokus på praktiske redskaber til organisationer, som 
ønsker at fremstille deres egne indekseringsskabeloner. Principper synes imidlertid at have forskellige underliggende strukturer. De refererede tests demonstrerer, at brugertags bliver tildelt uden nogen restriktioner i.f.t. typer og antal, medens det forholder sig anderledes med professionelle indeksører, som overholder retningslinjer, der definerer typer og minimerer antallet af tildelte termer. Testresultaterne bemærker også ligheder og forskelligheder mellem Flickr-taggernes tags og kontrollerede indekstermer, som anvendes $\mathrm{i}$ billedsamlinger. Testene præsenterer en vejledning til at skabe informativ og deskriptiv tekst til fotos. Vejledningen gør klart, hvilke attributter i.f.t. billedsammenhæng og -indhold der bliver udtrykt i brugernes daglige billedbehov. Vejledninger med både ukontrollerede og kontrollerede emneord, som blev præsenteret $\mathrm{i}$ 2011, bliver brugt som basis for udvikling af nye tilgange indenfor datalogien i 2017. (Conduit and Rafferty, 2007; Rorissa, 2010; Tang and Carter, 2011; Yoon and Chung, 2011; Matusiak, 2013; Konkova et al., 2014; Piras and Giacinto, 2017)

Artikler fra den tredje sub-kategori, Emotions, behandler ét specifikt niveau. En forsker sætter spørgsmålstegn ved, om brugere virkelig behøver systemer, der kan benyttes til indeksering/søgning efter følelser i fotografier, men andre artikler tager det for givet, at der eksisterer et sådant behov, og koncentrerer sig om at indeksere følelsesaspekter. Der er en overvejede tro på, at følelsesmæssige beskrivelser af digitale fotografier kan gøres bedre ved konnotative meddelelser især vedrørende meninger og opfattelser. En test foreslår at tildele et mindre antal populære følelsesmæssige termer til flere poster for at forbedre indekseringen. Den konnotative meddelelse er vanskelig, og en unders $\varnothing$ gelse tester MIR (Music Information Retrieval system), et musiksystem med tilsvarende konnotative deskriptor problemer. (Schmidt and Stock, 2009; Neal, 2010; Yoon, 2010; Yoon, 2011a)

Den tredje kategori, Retrieval, har det største antal af sub-kategorier, men ikke flest akademiske artikler. Artiklerne i den første sub-kategori Framework handler om basic-level kategorierne. Det universelle ved disse kategorier anvendes til at konstruere forbindelser mellem klassifikationssystemer og brugercentreret indeksering. Unders $\emptyset$ gelsesresultaterne foreslår, at etiketterne for individuelle fotos og deres genstande udg $\varnothing r$ basic-level, medens etiketterne for grupper af fotos er på det superordinate-level. Det subordinate-level bliver sjældent brugt af deltagerne. Drøftelserne af undersøgelserne er åbne dvs. uden konklusion. (Rorissa, 2008; Rorissa and lyer, 2008; Hajibayova, 2013)

Unders $\varnothing$ gelser om CBIR (Content Based Image Retriveal) i den anden sub-kategori handler om søgning efter faktuelle ting i et billede. I CBIR-artiklerne beskrives fremfinding af lagrede billeder, idet forskellige elementer, som automatisk ekstraheres fra selve billedet, sammenlignes - eksempelvis. farve, tekstur og form. Viden om CBIR er nødvendig, og undersøgelserne viser, at brugere, som er interesseret i disse systemer, primært er interesserede i søgning efter formelle karakteristika i fotografier. (Beaudoin, 2015; Mounika et al., 2016)

Artiklerne i den tredje sub-kategori, Queries, fokuserer på design og udvikling af effektive fotosøgesystemer baseret på aktuelle søgninger efter digitale billeder. Spørgsmålsformulering og specielt reformulering er et vanskelligt område, og et tesaurussystem er blevet foreslået etableret til visning af synonymer og hierarkiske termer, som kan hjælpe brugerne til at konstruere deres søgninger mere korrekt og effektivt. Unders $\emptyset$ gelsesresultaterne indikerer, at formatrelaterede termer og kontekstuelle informationer, som relaterer sig til billedet, er vigtige, selvom domæner også synes at influere søgeudviklingen. Power-tags er en ny søgemetode i informationsgenfindingssystemer, og en artikel præsenterer en skitse til en algoritme, som kan anvende denne metode. (Jansen , 2008; Chung and Yoon, 2009; Choi and Hsieh-Yee, 2010; Peters and Stock, 2010; Hung, 2012; Choi, 2013; Park et al., 2015)

I den fjerde sub-kategori, Taxonomy, testes en prototype til spørgsmålstaksonomi til billedsøgning. Organisationer arbejder med generiske og specifikke spørgsmål, og der er enighed om, at de generiske er de mest anvendte. Andre undersøgelser indikerer, at en "down-top" tilgang er at foretrække, og at specifikke genstande og begivenheder, som ses i fotografiet, er det mest almindelige niveau også i beskrivelsen. Andre unders $\varnothing$ gelser igen konkluderer, at søgeadfærden er influeret af spørgsmålstypen og afhænger af brugeren (arbejds- eller fritidsspørgsmål). Resultaterne påpeger vigtigheden af at overveje spørgsmålskategorier for at 
forstå brugeradfærd på billedsøgningsplatforme. En sidste undersøgelse ser på forskellige designforslag, og undersøger om billedsøgemodellen, som de fleste søgemaskiner anvender, hvor emneord er input og en lineær liste på 20 svar er output, er formålstjenlig. (Rafferty and Hidderly, 2007; Lee and Neal, 2010; Tirilly et al., 2012; Maniu et al., 2013; Göker et al., 2016; Konkova, MacFarlane and Gôker, 2016)

Den femte sub-kategori User Needs er baseret på undersøgelser af brugere og ikke på forbedringer af systemer. Abstrakte attributter bliver for det meste brugt til søgning, når brugerne påtænker at benytte fotografiet som kilde til genstande, medens specifikke attributter gennems $\varnothing$ ges, når fotografiet bruges til datakilder. Fotografier bliver oftest $s \varnothing \mathrm{gt}$ ifm. brugerens arbejde, behov og forskningsområde. (Enser et al., 2007; Andre et al., 2009; Chung and Yoon, 2011; Yoon, 2011b; Reilly and Thompson, 2014; Albertson, 2015)

Konkluderende ses der ikke store forandringer i forskningsfokus i artiklerne. Litteraturoversigten viser dog, at billedindeksering nu også inkluderer modeller, motivation for tagging, crowdsourcing, redigering af klassifikationssystemer og tesaurusser, som også har betydet en $\emptyset$ get brugerinvolvering i indekseringsprocessen. Den største forandring er adgangen til store billedsamlinger høstet fra sociale netværker som Flickr etc. Samlinger giver forskere nye "testbeds" til at forbedre eller afprøve forskningshypoteser på en skala, der ikke har været mulig $f ø r$.

\section{Billedforskningsdomænet}

For at afdække videnstrukturen i billedforskningsdomænet er der udført bibliometriske analyser af den undersøgte litteratur. I litteraturstudiet er 70 forskningsartikler inkluderet og dækker ca. en 10-årig periode. For at få en bedre forståelse af udviklingen af billedområdet er der udført en co-citations analyse af tidskrifter samt en analyse af forfattere. Analyserne er baseret på data fra Web of Knowledge -citationsdatabasen, hvor 56 af de 70 artikler fra litteraturstudiet blev fundet indekseret. Netværksanalysen og generering af et co-citationskort blev udført ved hjælp af VOS-viewer software version 1.6.5. (Van Eck \& Waltmann, 2014) I figur 3 fremgår cocitationskortet for de ti artikler, der har opnået flest citater blandt de analyserede artikler. Afstanden mellem de noder, der vises på kortet, er en indikation af, hvor "tæt" to artikler kan betragtes at være. Kort afstand mellem to noder tilkendegiver, at artiklerne ofte citeres sammen.

Der kan identificeres to centrale klynger fokuseret på tidsskriftet Journal of the American Society for Information Science and Technology (JASIST) og konferenceberetninger fra den årlige Association for Information Science and Technology (ASIS\&T) konference. Begge udgives af Association of Society for Information Science and Technology. En anden central publikation er Information Processing and Management (IPM) udgivet af Elsevier. Givet fokusset i de analyserede artikler er det måske ikke overraskende, da alle tre publikationer er centrale indenfor informationsvidenskab. Jvf. den danske Bibliometriske Forsknings Indikator er JASIST og IPM kategoriseret på niveau 2. Kortet viser også, at der citeres fra tidsskrifter fra andre faglige domæner, primært psykologi og datalogi. På venstre side er Cognitive Psychology (Elsevier) med 29 citater og Psychological Review (American Psychological Association) med 10 citater. Datalogi og relaterede felter vises på højre side af kortet eksemplificeret ved at Lecture Notes in Computer Science (Springer) modtager 34 citater samt IEEE Transactions on Pattern Analysis og Machine Intelligence. 


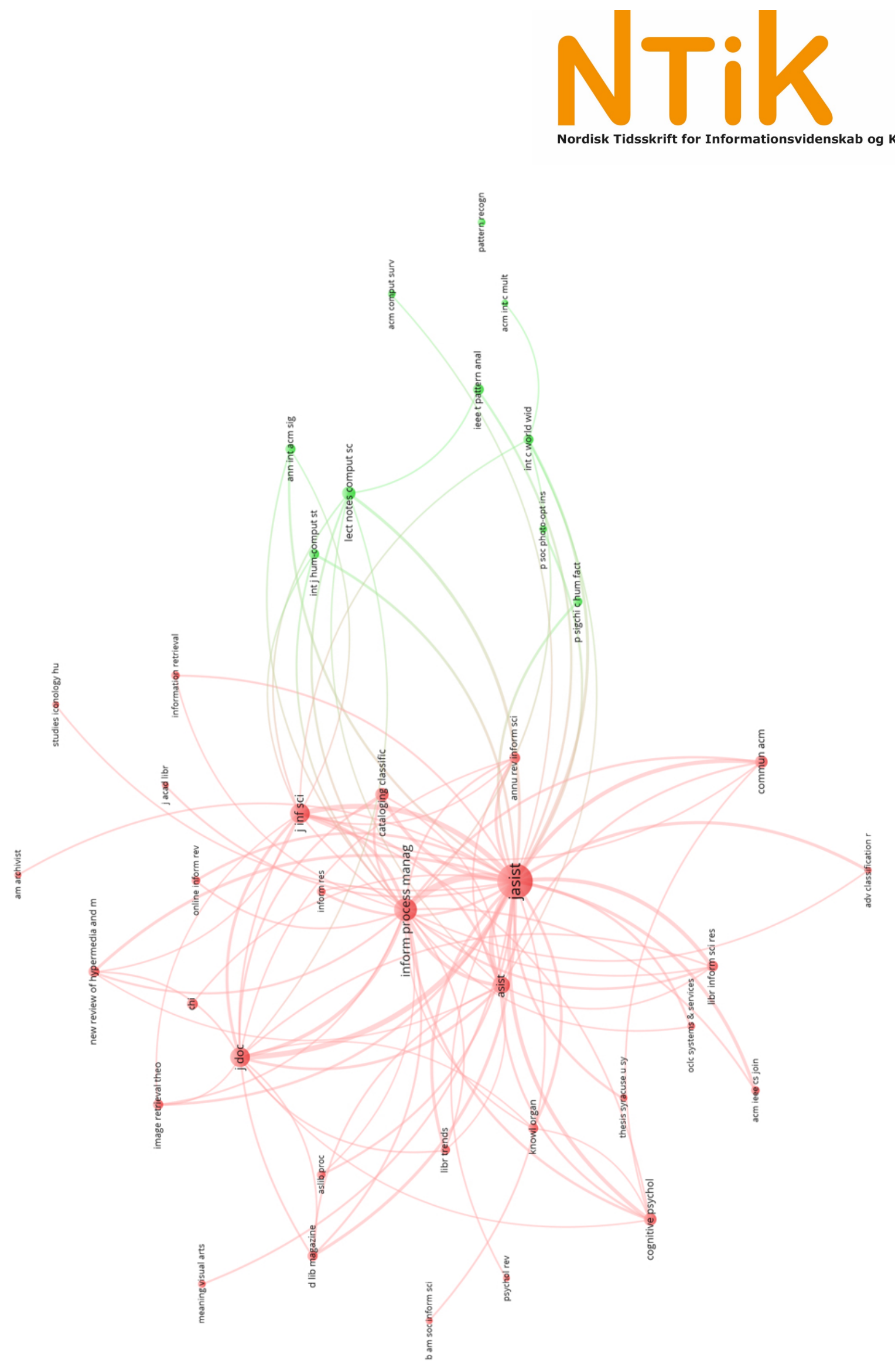

Figur 3. Co-citationskort for tidsskrifter 


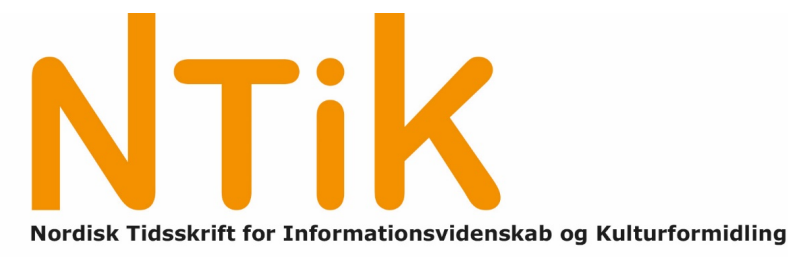

Samlet set viser co-citationskortet et stærkt center koncentreret om informationsvidenskab, men påvirket både af forskningen indenfor psykologi og datalogi.

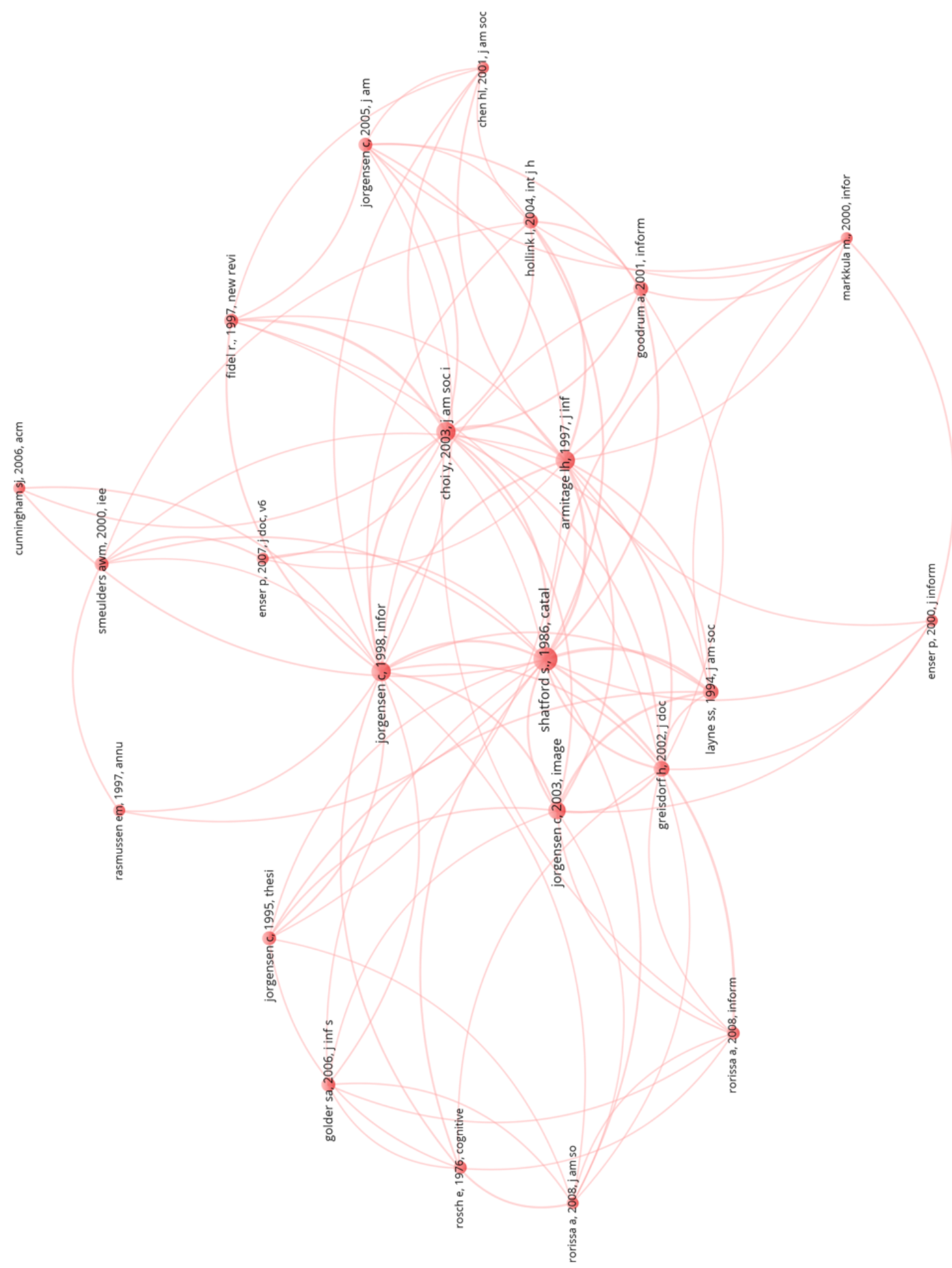

Figur 4. Co-citationskort for citerede referencer 
For at få et overblik over, hvilken forskning de gennemgåede artikler bygger på, er en co-citationsanalyse af citerede artikler udført. Analysen illustrerer den forskning, som har haft den største indflydelse på området billedindeksering. Artikler med mere end 10 citationer er inkluderet. Dette var tilfældet for 23 artikler (Figur 4). Shatford's artikel fra 1986, hvor hun præsenterer sit skema for indeksering af billeder, havde 26 referencer. Desuden er Rorissa (2008) og Rorissa, Clough og Deselars (2008) ofte citeret for at præsentere hver deres forskning om indeksering af fotografier.

Panofskys fortolkningsmodel motiverer Shatford i hendes 1986 artikel. Panofsky's model for billedanalyse er oprindeligt udviklet for renæssancekunst, men Shatford tilpasser Panofsky's model så den dækker billedindeksering generelt. Hun skriver, at det er "muligt at anvende modellen på ethvert repræsentativt arbejde "(Shatford 1986, s. 43). Selv om hendes artikel er fra 1986 og billeddigitalisering har ændret miljøet, har Panofsky/Shatford modellen stadig en stærk indflydelse på næsten alle forskningsartikler om indeksering af billeder. Rorissa anerkender Shatford og hendes arbejde, men er i sin forskning mere påvirket af udvikling af sociale medier og fokuserer derfor på forskning, som er mere relateret til sociale netværk. Rorissa henter inspiration fra psykologi og anvender Rosch et al. s (1976) "basic level theory". Rorissas mål er at finde en kategorisering, der nemt kan anvendes af både professionelle og amatører. Hans indflydelse på domænets udvikling har dog været begrænset.

Jörgensen er repræsenteret med 4 artikler, hvor hendes 2003-artikel modtager 18 citater. Artiklen handler om billedgenfinding og foreslår st $\varnothing$ ttesystemer til optimering af søgninger. De fleste af Jörgensens $\varnothing v$ vige bidrag handler om indeksering af billeder og udvikling af indekseringssystemer. I alt er hun den mest citerede forfatter med 63 citater i alt.

Foruden Jörgensen, Shatford (hendes 1994-artikel om indeksering er vist som Layne, S.S.) og Rasmussen (1997) er Markkula og Sormunen (n.d.) citeret for deres arbejde med billedindeksering. Kun en af de citerede artikler omhandler "collaborative" tagging-adfærd i.e. Golder og Huberman (2006). Papiret fra Golder drejer sig ikke om billedindeksering per se, men der henvises til Shatford, Rorissa og Rosch.

Fire forfatteres artikler handler om aspekter af informationsgenfinding: Smeulders et al. (2000), Goodrum og Spink (2001), Enser (2000) og Fidel (1997). To artikler om brugeradfærd og informationssøgning er citeret: Armitage og Enser (1997) og Cunningham og Masoodian (2006). For nyere artikler om billedbehandling henvises til Chen (2001) og Choi og Rasmussen (2003).

Femten artikler er publiceret fra 2000 og frem, Seks artikler er publiceret mellem 1990 og 1999 og 2 artikler før 1990. Dette er i tråd med andre citationsanalyser, hvor flertallet af de citationer, en artikel opnår, ligger indenfor et relativt kort kronologisk tidsrum fra udgivelsesåret. Analysen illustrerer dog også, at centrale artikler indenfor faget opnår citationer længe efter publiceringen som Shatford (1986) viser.

I et studie fra 2001 fandt Chu, at specielt to hovedudviklinger kan identificeres i billedforskningsfeltet: contentbased og description-based billedindeksering og genfinding. Content-based indeksering er automatisk processering af billedattributter f.eks. i form af tekstinformation knyttet til billedet, men også udtræk af "features" fra billedet selv. Dette kan f.eks. være tekst i form af tekniske oplysninger om billedet (farvesammensætning, mønster etc.). Description-based indeksering er en manuel indeksering af billedet (tildeling af emneord, beskrivelse af billedet motiv, fotograf etc.). Chu (2001) fandt i sin analyse at description based indeksering fortrinsvis kan henføres til informationsvidenskabelig forskning, hvorimod Content-based indeksering behandles af Computer Science uden megen interaktion mellem de to fagfelter. I vores analyse ser vi samme opdeling af billedforskningen som Chu, men baseret på de udførte bibliometriske analyser ser vi en brug af forskningen fra datalogien i den informationsvidenskabelige billedforskning. Udviklingen tyder på, at informationsvidenskaben i perioden 2005 - 2017 er blevet mere opmærksom på mulighederne i kombinationen af manuel indeksering og algoritmisk baseret indeksering af billeder. 


\section{Konklusion og nye udviklinger}

Vi lever i den digitale æra, og teknologi og sociale netværker påvirker i høj grad vores dagligdag. Vi har en tendens til at tro, at problemer kan løses ved teknologi alene uden først at tage stilling til, hvilken indflydelse en teknologi kan få, og dermed hvilke udfordringer, der bør løses, før en teknologi indføres. Vi har stadig brug for forskning om billeder, selvom teknologien til at fange og behandle billeder udvikler sig med stor hastighed. Analysen viser ikke en adaption af erfaringerne fra akademisk billedforskning til de private billeder på sociale medier. Motiveringen til at levere metadata ser ud til at være drevet af personlig fordel mere end samfundsmæssige hensyn, dvs. at støtte individets tilstedeværelse på de sociale medier.

Tilgangen i forskning til analyse af billedindeksering og kategorisering af tags er stadig baseret på Panofsky og Shatford's forskning. Vi ser dog også i litteraturen eksperimenter i indeksering og brug af billeder på sociale medier, og disse eksperimenter fører til nye indsigter. Med introduktionen af crowdsourcing i professionelle billedsamlinger er en streng overholdelse af veletablerede retningslinjer blevet udfordret, men crowdsourcing synes dog at fungere som et værdifuldt supplement til den professionelle, formaliserede indeksering. Store crowdsourcing projekter, hvor almindelige brugere i samarbejde med forskere tagger billedsamlinger, peger på nye måder at inddrage brugerne i forskningen og kan i fremtiden få en betydning for, hvordan billeder på sociale medier kan tagges automatisk ved hjælp af kunstig intelligens (AI). Fei Fei Li, som er leder af Vision Lab and the Artificial Intelligence Lab ved Stanford (Savage, 2016), fik involveret næsten 50.000 brugere i et tagging projekt. Hun anvendte Amazon Mechanical Turk, som med micro betaling af brugerne fik tagget en samling på næsten en milliard billeder. Brugernes tags blev anvendt til at træne computersoftware i automatisk billedindeksering. Samlingen er tilgængelig på image-net.org.

En anden tilgang er udviklingen af nye videndelingsværktøjer i billedbeskrivelse. Et eksempel på "blended-mode" ved indeksering gives af Springer et al. (2008), hvor brugere på baggrund af simple guidelines tagger historiske fotos allerede indekseret af LC. Denne type af overordnede retningslinjer kunne også anvendes på andre domæner. Analyse af brugeradfærd, hvor forskere ser på brugerforespørgsler og brugernes anvendelse af kategorier for at forstå brugernes adfærd på billedsøgningsplatforme, er grundigt undersøgt, og det samme gælder for modeller til genfinding.

Fra litteraturstudiet kan vi også se, at samarbejdet mellem informationsvidenskab og datalogi er intensiveret, og CBIR, som er afledt af mønstergenkendelse ( $f x$ fingeraftryk, røntgenbilleder og ansigtsgenkendelse), er blot ét eksempel. I akademisk billedforskningslitteratur er CBIR specifikt blevet brugt til automatisk kategorisering efter farve, form, tekstur osv.

Fei-Fei Li (2016) udtaler, at "computers are roughly as good at describing the content of images as a three-yearold child." Hun siger endvidere, at "The complete level, on par with an adult, college-degreed human, I think is going to be a long way of". Så vi kan ikke forvente, at algoritmer endnu kan vise ægte visuel intelligens, selvom computeren i dag udfører bedre undersøgelser til at forstå indholdet af et fotografi, end det var tilfældet for bare nogle få år siden. Et af problemerne er som eksempel at genkende en genstand eller et objekt, når det præsenteres fra forskellige vinkler.

Fei-Fei Li giver et eksempel med 2 billeder af en kat præsenteret i hhv. Figur 5 og 6 . Computeren generer en template ud fra billedet af Cat1 (figur 5). Problemet opstår, hvis denne skabelon for en kat sammenholdes med Cat2 (figur 6), fordi mønsteret i billedet ændres. Det kræver en ny processering at forstå, at de 2 skabeloner begge henviser til det samme semantiske udtryk CAT. Computeren skal trænes. 


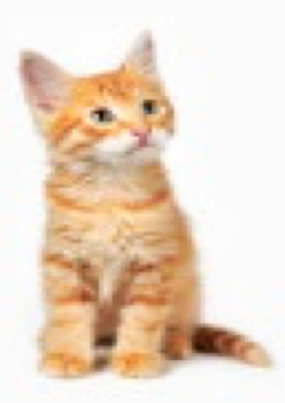

Figur 5.

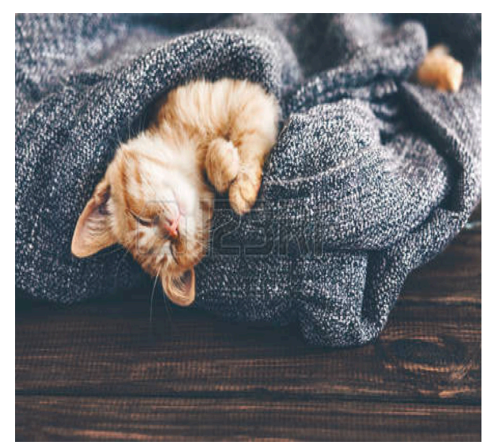

Figur 6.

Computerprogrammer kan korrekt registrere personer i en båd i et bestemt foto, men hvis man spørger, hvad der sker i båden, er vi ikke på et niveau, hvor computeren kan fortolke, hvad der foregår (Savage, 2016). Vi mennesker kan relativt nemt fortolke billeder, men billeder er typisk polysemiske, hvilket for en computer er en udfordring.

Rüger (2011, s. 172) hævder, at "users who submit an image ... could have a dozen different information needs in mind," however, "user feedback can change the weights of features in content-based retrieval scenarios". Richard Zemel, forsker $\mathrm{i}$ at træne systemer til at besvare vilkårlige spørgsmål om et billede, men arbejdet er stadig på et tidligt stadie. Dette skyldes, at "the currently available dataset is not large enough" (Ren, Kiros og Zemel, 2015, s. 8) for computeren til at lære. Baseret på citaterne fra Fei-Fei Li, Rüger og Zemels ovenfor kan det konkluderes, at der stadig er behov for forskning i human billedindeksering og genfinding, uagtet at det måske $i$ løbet af ikke så mange år vil være muligt ved hjælp af bl.a. Al at forstå indholdet i billeder. Hvis computere skal lære nye måder at genkende billeder på, skal forskerne være på forkant med billedforskningen.

En udfordring for at kunne anvende Al i billedindeksering er, at genkendelsen af følelsesmæssige udtryk endnu ikke er muligt med stor sikkerhed, hvorfor vi stadig står over for spørgsmålet om computers visuelle evner i forhold til den semantisk forståelse i den menneskelige hjerne. Som Fei- Fei Li (2016) skriver, så skal vi fokusere på symbiosen af tekstlige beskrivelser og billeder. Jf. Zemel (Ren, Kiros og Zemel, 2015) så er en omfangsrig database med spørgsmål og svar om billeder nødvendig for at computeren kan lære.

Der opstår bestandigt nye måder at bruge fotografiet på i videnskaben, i pressen og i det private liv. Dette sker i kraft af den teknologiske udvikling og dernæst ved at forskellige faglige områder smelter sammen. Der er ingen grund til at tro, at dette ikke vil forsætte (som citeret i Ørnager \& Lund, 2018 s. 84). Nye udviklingsområder kan forventes i forskning og teknologi, og fotografiet vil fortsætte med at eksistere, hvis vi tror på, at udsagnet " $a$ picture is worth a thousand words" stadig har gyldighed. Derudover har vi Fei-Fei Li's udsagn om, at computere ikke er i stand til at dechifrere, hvad der foregår i et billede (Savage, 2016). Hendes udtalelser peger på nødvendigheden af ny forskning i kombinationen af billedfeltet og tekstgenkendelse, og med den stadige udvikling af computerteknologien er der et stort potentiale for et tæt samarbejde med datalogi og andre fagområder.

Vi har skitseret flere nye forskningsområder baseret på litteraturstudiet, men dette dækker dog langt fra alle de muligheder, som kan tænkes. Der er ikke tvivl om, at der stadig venter store udfordringer for de forskere, som $\emptyset n$ nker at dykke ned i de umådelige mængder af fotografier, som nu er til rådighed for forskningen. 


\section{Referencer}

Albertson, D. (2015). Visual information seeking. Journal of the American Society for Information Science and Technology, 66(6), 1091-1105. DOI: 10.1002/asi.23244

Ames, M. and Naaman, M. (2007). Why we tag: Motivations for annotation in mobile and online media. $\mathrm{CHI}$ 2007, April 28-May 3, 2007, San Jose, CA, 1-10. DOI: 10.1145/1240624.1240772

Andre, P., Cutrell, E., Tan, D. S., and Smith, G. (2009). Designing novel image search interfaces by understanding unique characteristics and usage. In Gross, T. et al. (Eds.). Human-Computer Interaction - INTERACT 2009, 340353. Lecture Notes in Computer Science, vol. 5727. Springer, Berlin, Heidelberg. DOI:

10.1007/9783642036583_40

Angus, E., Stuart, D., and Thelwall, M. (2010). Flickr's potential as an academic image resource: An exploratory study. Journal of Librarianship and Information Science, 42(4), 268-278. DOI: 10.1177/0961000610384656

Barthes, R. (1964). Rhetoric of the Image. In Heath, S. (Ed.) Roland Barthes: Image - Music - Text, London: Fontana Press, 1977. Originally published as "Rhetorique de l'image" in Communications 4: 40-51. DOI: 10.1007/978-1-349-03518-2

Beaudoin, J. E. (2012). Context and its role in the digital preservation of cultural objects. D-Lib Magazine, 18(11/12). DOI: 10.1045/november2012-beaudoin1

Beaudoin, J. E. (2014). A framework of image use among archaeologists, architects, art historians and artists. Journal of Documentation, 70(1), 119-147. DOI: 10.1108/JD-12-2012-0157

Beaudoin, J. E. (2015). Content-based image retrieval methods and professional image users. Journal of the American Society for Information Science and Technology, 67(2), 350-365, 2016.

Beaudoin, J. E. (2016). Describing images: A case study of visual literacy among library and information science students. College \& Research Libraries, 77(3), 376-392. DOI: 10.5860/crl.77.3.376

Benson, A. C. (2015). Image descriptions and their relational expressions: a review of the literature and the issues. Journal of Documentation, 71(1), 143-164. DOI: 10.1108/JD-07-2013-0093

Chen, H., Kochtanek, T., Burns, C. S., and Shaw, R. (2010). Analyzing users' retrieval behaviors and image queries of a photojournalism image database. The Canadian Journal of Information and Library Science, 34(3), 249-270. DOI: 10.1353/ils.2010.0003

Choi, Y. (2013). Analysis of image search queries on the web: Query modification patterns and semantic attributes. Journal of the American Society for Information Science and Technology, 64(7), 1423-1441. DOI: 10.1002/asi.22831

Choi, Y. and Hsieh-Yee, I. (2010). Finding images in an online public access catalogue: Analysis of user queries, subject headings, and description notes. The Canadian Journal of Information and Library Science 34(3), 271298. DOI: 10.1353 /ils.2010.0004

Choi, Y. and Rasmussen, E. M. (2003). Searching for images: The analysis of users' queries for image retrieval in American history. Journal of the Association for Information Science and Technology, 54(6), 498-511. DOI: 10.1002/asi.10237

Christensen, H. D. (2017). Rethinking image indexing? Journal of the Association for Information Science and Technology, 68(7), 1782-1785. DOI: 10.1002/asi.23812 
Chu, H. T. (2001). Research in image indexing and retrieval as reflected in the literature. Journal of the American Society for Information Science and Technology. 52(12), 1011-1018.

Chung, E. K. and Yoon, J. W. (2009). Categorical and specificity differences between user-supplied tags and search query terms for images. An analysis of Flickr tags and Web image search queries. Information Research, 14(3).

Chung, E. K. and Yoon, J. W. (2011). Image needs in the context of image use: An exploratory study. Journal of Information Science, 37(2), 163-177. DOI: 10.1177/0165551511400951

Conduit, N. and Rafferty, P. (2007). Constructing an image indexing template for The Children's Society. Users' queries and archivists' practice. Journal of Documentation, 63(6), 898-919. DOI: 10.1108/00220410710836411

Drew, S. and Guillemin, M. (2014). From photographs to findings: visual meaning-making and interpretive engagement in the analysis of participant generated images. Visual Studies, 29(1), 54-67. DOI:

10.1080/1472586X.2014.862994

Enser, P. (2000). Visual image retrieval: seeking the alliance of concept-based and content-based paradigms. Journal of Information Science, 26(4), 199-210. DOI: 10.1177/0165551004233212.

Enser, P. G. B., Sandom, C. J., and Lewis, P. H. (2005). Automatic annotation of images from the practitioner perspective. In Leow, W.-K. et al. (Eds.), CIVR 2005, LNCS 3568, 497-506. DOI: 10.1007/11526346_53

Enser, P. G. B., Sandom, C. J., Hare, J. S., and Lewis, P. H. (2007). Facing the reality of semantic imageretrieval. Journal of Documentation, 63(4), 465-481. DOI: 10.1108/00220410710758977

Estelle's-Arolas, E. and Gonza'lez-Ladro'n-de-Guevara, F. (2012). Toward an integrated crowdsourcing definition. Journal of Information Science 38(2), 189-200. DOI: 10.1177/0165551512437638

Fauzi, F. and Belkhatir, M. (2013). Multifaceted conceptual image indexing on the world wide web. Information Processing and Management 49, 420-440. DOI: 10.1016/j.ipm.2012.08.001

Fauzi, F. and Belkhatir, M. (2014). Image understanding and the web: a state-of-the-art Review. Journal of Intelligent Information Systems, 43, 271-306. DOI: 10.1007/s10844-014-0323-6

Fei-Fei, L. (2016). How we teach computers to understand pictures. TED Talk. Lokaliseret 7-12-2018 på: https://www.youtube.com/watch?v=40riCqvRoMs

Glaser, B. (1992). Basics of Grounded Theory Analysis. Mill Valley, CA: Sociology Press.

Glaser, B. and Strauss, A. (1967). The Discovery of Grounded Theory. Chicago: Aldine.

Goker, A., Butterworth, R., MacFarlane. A., Ahmed, T. S., and Stumpf, S. (2016). Expeditions through image jungles. Journal of Documentation, 72(1), 5-23, DOI: 10.1108/JD-01-2014-0019

Hajibayova, L. (2013). Basic-level categories: A review. Journal of Information Science, 39(5) 676-687. DOI: $10.1177 / 0165551513481443$

Huang, H. and Jorgensen, C. (2013). Characterizing user tagging and co-occurring metadata in general and specialized metadata collections. Journal of the American Society for Information Science and Technology, 64(9), 1878-1889. DOI: 10.1002/asi.22891

Hung, T. Y. (2012). An analysis of photo editors' query formulations for image retrieval. Journal of Librarianship and Information Studies, 4(1), 13-16. 
Informationsordbogen (2018). Det Informationsvidenskabelige Akademi. Københavns Universitet.

Jansen, B. J. (2008). Searching for digital images on the web. Journal of Documentation, 64(1), 81 -101. Permanent link to this document: http://dx.doi.org/10.1108/00220410810844169

Jörgensen, C. (1995). Image attributes: An investigation (Indexing systems, retrieval systems, computerized). Unpublished doctoral dissertation, Syracuse University, NY.

Jörgensen, C. (1998). Attributes of images in describing tasks. Information Processing and Management, $34(2 / 3), 161-174$

Jörgensen, C. (2003). Image retrieval: theory and research. The Scarecrow Press, Lanham, MA and Oxford.

Jörgensen, C. (2007). Image access, the semantic gap, and social tagging as a paradigm shift. 18th Annual ASIS SIG/CR Classification Research Workshop, 1-9, DOI: 10.7152/acro.v18i1.12868

Jörgensen, C. (2010). Still image indexing. Encyclopedia of Library and Information Sciences. 3rd ed. DOI: 10.1081/E-ELIS3-120044380

Jörgensen, C. and Jörgensen, P. (2005). Image querying by image professionals. Journal of the American Society for Information Science and Technology, 56(12), 1346-1359. https://doi.org/10.1002/asi.20229

Jörgensen, C., Stvilia, B., and Wu, S. (2013). Assessing the relationships among tag syntax, semantics, and perceived usefulness. Journal of the American Society for Information Science and Technology, 65(4), 836-849, 2014.

Klenczon, W. and Rygiel, P. (2014). Librarian cornered by images, or how to index visual resources. Cataloging \& Classification Quarterly, 52(1), 42-61. DOI: 10.1080/01639374.2013.848123

Konkova, E., Goker, A.S., Butterworth, R., \& MacFarlane, A. (2014). Social Tagging: Exploring the Image, the Tags, and the Game. Knowledge Organization, 41(1), 57-65.

Kovacs, B. L. and Takacs, M. (2014). New search method in digital library image collections: A theoretical inquiry. Journal of Librarianship and Information Science, 46(3), 217-225. DOI: 10.1177/0961000614526611

Konkova, E., MacFarlane, A., and Goker, A. (2016). Analysing creative image search information needs. Knowledge Organization, 43(1).

Layne, S. S. (1994). Some issues in the indexing of images. Journal of the American Society for Information Science, 4(8), 583-588.

Lee, H. J. and Neal, D. (2010). A new model for semantic photograph description combining basic levels and user-assigned descriptors. Journal of Information Science, 36(5), 547-565. DOI: 10.1177/0165551510374930

Lin, Y. L., Trattner, C., Brusilovsky, P., and He, D. (2015). The impact of image descriptions on user tagging behavior: A study of the nature and functionality of crowdsourced tags. Journal of the American Society for Information Science and Technology, 66(9), 1785-1798. DOI: 10.1002/asi.23292

Maniu, S., O'Hare, N., Aiello, L. M., Chiarandini, L., and Jaimes, A. (2013). Search behavior on photo sharing platforms, presented at IEEE International Conference on Multimedia and Expo (ICME), July 15-19, 2013, San Jose, CA. DOI: 10.1109/ICME.2013.6607496

Matusiak, K. K. (2013). Image and multimedia resources in an academic environment: A qualitative study of students' experiences and literacy practices. Journal of the American Society for Information Science and Technology, 64(8), 1577-1589. DOI: 10.1002/asi.22870 
Moher, D., Liberati, A., Tetzlaff, J., and Altman, D.G. (2009). Preferred reporting items for systematic reviews and meta-analyses: the PRISMA statement, Annals of Internal Medicine, 151(4), 264-269.

Mounika, B., Sowmya, Y., Pasala, S., and Sravani, A. (2016). Content-based image retrieval using color. International Journal of Applied Engineering Research, 11(6), 4331-4334.

Nakatsu, R. T., Grossman, E. B., and lacovou, C. L. (2014). A taxonomy of crowdsourcing based on task complexity. Journal of Librarianship and Information Science, 40(6), 823-834. DOI:

$10.1177 / 0165551514550140$

Nations, D. (2017). What Is Social Media? Explaining the Big Trend.

Neal, D. (2008). News photographers, librarians, tags, and controlled vocabularies: Balancing the forces. Journal of Library Metadata, 8(3), 199-219. DOI: 10.1080/19386380802373936

Neal, D. (2010). Emotion-based tags in photographic documents: The interplay of text, image, and social influence. The Canadian Journal of Information and Library Science 34(3), 329-353. DOI: 10.1353/ils.2010.0000

Nov, O. and Ye, C. (2010). Why do people tag? Motivations for photo tagging. Communications of the ACM, 53(7), 128-131. DOI: 10.1145/1785414.1785450

Obar, J. and Wildman, S. (2015). Social media definition and the governance challenge: An introduction to the special issue. Telecommunications Policy, 39(9), 745-750. DOI: 10.1016/j.telpol.2015.07.014

Ornager, S. (1997). Image retrieval: Theoretical analysis and empirical user studies on accessing information in images. Proceedings of the American Society for Information Science Annual Meeting 34: 202-11.

Panofsky, E. (1962). Studies in Iconology: Humanistic Themes in the Art of Renaissance. Reprinted, New York: Harper and Row.

Park, J. Y., O'Hare, N., Schifanella, R., Jaimes, A., and Chung, C. W. (2015). A large-scale study of user image search behavior on the Web. Presented at CHI 2015, Crossings, April 18-23, 2015, Seoul, Korea, 985-994. DOI: $10.1145 / 2702123.2702527$

Petek, M. (2012). Comparing user-generated and librarian-generated metadata on digital images. OCLC Systems \& Services: International Digital Library Perspectives, 28(2), 101-111. DOI: 10.1108/10650751211236659

Peters, I. and Stock, W. G. (2010). Power tags in information retrieval, Library Hi Tech, 28(1), 81- 93. Permanent link to this document: http://dx.doi.org/10.1108/07378831011026706

Piras, L. and Giacinto, G. (2017). Information fusion in content based image retrieval: A comprehensive overview. Information Fusion, 37, 50-60. DOI: 10.1016/j.inffus.2017.01.003

Rafferty, P. and Albinfalah, F. (2014). A tale of two images: the quest to create a story-based image indexing system. Journal of Documentation, 70(4), 605-621. DOI: 10.1108/JD-10-2012-0130

Rafferty, P. and Hidderley, R. (2007). Flickr and democratic indexing: Dialogic approaches to indexing. Aslib Proceedings: New Information Perspectives, 59(4/5), 397-410. DOI: 10.1108/00012530710817591

Ransom, N. and Rafferty, P. (2011). Facets of user-assigned tags and their effectiveness in image retrieval. Journal of Documentation, 67(6), 1038-1066. http://dx.doi.org/10.1108/00220411111183582

Reilly, M. and Thompson, S. (2014). Understanding ultimate use data and its implication for digital library management: A Case Study. Journal of Web Librarianship, 8(2), 196-213. DOI: 10.1080/19322909.2014.901211 
Ren, M., Kiros, R., and Zemel, R.S. (2015). Exploring models and data for image question answering. In proceedings Advances in neural information processing systems 28: Annual Conference on Neural Information Processing Systems 2015, December 7-12, Montreal, Qubec, Canada, 2953-2961.

Rorissa, A. (2008). User-generated descriptions of individual images versus labels of groups of images: A comparison using basic level theory. Information Processing and Management 44, 1741-1753.

Rorissa, A. (2010). A Comparative Study of Flickr Tags and Index Terms in a General Image Collection. Journal of the American Society for Information Science and Technology, 61(11), 2230-2242

Rorissa, A., \& Iyer, H. (2008). Theories of Cognition and Image Categorization: What Category Labels Reveal About Basic Level Theory. Journal of the American Society for Information Science and Technology, 59(7), 1-10.

Rorissa, A., Clough, P., \& Deselaers, T. (2008). Exploring the Relationship Between Feature and Perceptual Visual Spaces. Journal of the American Society for Information Science and Technology, 59(5), 770-784.

Rosch, E., Mervis, C. B., Gray, W., Johnson, D., and Boyes-Braem, P. (1976). Basic objects in natural categories. Cognitive Psychology, 8(3), 382-439. DOI: 10.1016/0010-0285(76)90013-X

Rüger, S. (2011). Multimedia resource discovery. In: Melucci M., Baeza-Yates R. (eds) Advanced Topics in Information Retrieval. 157-186. The Information Retrieval Series, vol 33. Berlin, Heidelberg: Springer

Savage, N. (2016). Seeing more clearly. Communications of the ACM, 59(1), 20-22. DOI: 10.1145/2843532

Schmidt, S. and Stock, W. G. (2009). Collective indexing of emotions in images. A study in emotional information retrieval. Journal of the American Society for Information Science and Technology, 60(5), 863-876. DOI: $10.1002 /$ asi.21043

Shatford, S. (1986). Analyzing the subject of a picture: A theoretical approach. Cataloguing and Classification Quaterly, 6(3), 39-62. DOI: 10.1300/J104v06n03_04

Springer, M., Dulabahn, B., Michel, P., Natanson, B., Reser, D., Woodward, D., and Zinkham, H. (2008). For the Common Good: The Library of Congress Flickr Pilot Project. Library of Congress, Washington.

Springer, M., Dulabahn, B., Michel, P., Natanson, B., Reser, D., Woodward, D., and Zinkham, H. (2008). For the Common Good: The Library of Congress Flickr Pilot Project. Washington: Library of Congress

Stewart, B. (2010). Getting the picture: An exploratory study of current indexing practices in providing subject access to historic photographs. The Canadian Journal of Information and Library Science 34(3), 297-327. DOI: 10.1353/ils.2010.0005

Stvilia, B. and Jorgensen, C. (2009). User-generated collection-level metadata in an online photo-sharing system. Library \& Information Science Research, 31, 54-65. DOI: 10.1016/j.lisr.2008.06.006

Stvilia, B. and Jorgensen, C. (2010). Member activities and quality of tags in a collection of historical photographs in Flickr. Journal of the American Society for Information Science and Technology, 61(12), 24772489. DOI: $10.1002 / a s i .21432$

Stvilia, B., Jorgensen, C., and Wu, S. (2012). Establishing the value of socially-created metadata to image indexing. Library \& Information Science Research, 34, 99-109. DOI: 10.1016/j.lisr.2011.07.011

Strauss, A. and Corbin, J. (1990). Basics of Qualitative Research. Grounded Theory Procedures and Techniques. Newbury Park, CA: Sage. 
Strauss, A. and Corbin, J. (1998). Basics of Qualitative Research Techniques and Procedures for Developing Grounded Theory, (2nd ed.). Sage Publications: London.

Tang, L. and Carter, J. A. (2011). Communicating image content. Proceedings of the Human Factors and Ergonomics Society 55th Annual Meeting. DOI: 10.1177/1071181311551102

Terras, M. (2011). The digital wunderkammer: Flickr as a platform for amateur cultural and heritage content. Library Trends, 59(4), 686-706. DOI: 10.1353/lib.2011.0022

Tirilly, P., Huang, C., Jeong, W., Mu, X., Xie, I., and Zhang, J. (2012). Image similarity as assessed by users: A quantitative study, presented at ASIST 2012, October 26-31, 2012, Baltimore, MD. DOI:

10.1002/meet.14504901180

Yoon, J. W. (2009). Toward a user-oriented thesaurus for non-domain-specific image collections. Information Processing and Management 45, 452-468. DOI: 10.1016/j.ipm.2009.03.004

Yoon, J. W. (2010). Utilizing quantitative users' reactions to represent affective meanings of an image. Journal of the American Society for Information Science and Technology, 61(7), 1345-1359. DOI: 10.1002/asi.21342.

Yoon, J. W. (2011a). A comparative study of methods to explore searchers' affective perceptions of images. IR Information Research, 16(2).

Yoon, J. W. (2011b). Searching images in daily life. Library \& Information Science Research, 33, 269-275. DOI: 10.1016/j.lisr.2011.02.003

Yoon, J. W. and Chung, E. (2011). Understanding image needs in daily life by analyzing questions in a social Q\&A site. Journal of the American Society for Information Science and Technology, 62(11), 2201-2213. DOI: 10.1002/asi.21637

van Eck, N. J., \& Waltman, L. (2014). Visualizing Bibliometric Networks. In Y. Ding, R. Rousseau, \& D. Wolfram (Eds.), Measuring Scholarly Impact (pp. 285-320). Cham: Springer International Publishing.

https://doi.org/10.1007/978-3-319-10377-8_13

Walsh, I., Holton, J. A., Bailyn, L., Fernandez, W., Levina, N., and Glaser, B. (2015). What grounded theory is ... A critically reflective conversation among scholars. Organizational Research Methods, 18(4), 581-599. DOI: $10.1177 / 1094428114565028$

Westman, S. and Oittinen, P. (2006). Image Retrieval by End-users and Intermediaries in a Journalistic Work Context. Information Interaction in Context: International Symposium on Information Interaction in Context: liiX: Copenhagen, Denmark, October 18-20, 2006, 102-110. DOI: 10.1145/1164820.1164843

White, H. D., \& McCain, K. W. (1998). Visualizing a discipline: An author co-citation analysis of information science, 1972-1995. Journal of the American Society for Information Science, 49(4), 327-355.

Zeng, M. L., Gracy, K. F., and Žumer, M. (2014). Using a semantic analysis tool to generate subject access points: A study using Panofsky's Theory and two research samples, presented at the International ISKO Conference, May 19-22, 2014, Krakow, Poland.

Ørnager, S. \& Lund, H. (2018) Images in social media. Categorization and organization of images and their collections. S.I.: Morgan \& Claypool 